\title{
Experience tourism: development possibilities in the Bioceanic Corridor
}

\author{
Turismo de experiência: possibilidades de desenvolvimento \\ no Corredor Bioceânico
}

\section{Turismo de experiencia: posibilidades de desarrollo en el Corredor Bioceánico}

\author{
Débora Fittipaldi Gonçalves ${ }^{1}$ \\ Mateus Boldrine Abrita ${ }^{1}$ \\ Arlinda Cantero Dorsa ${ }^{2}$
}

Recibido el 23 de June de 2021; revisado e aprobado el 18 de Sept. de 2021; aceptado el 13 de Oct. de 2021 DOI: http://dx.doi.org/10.20435/inter.v22i4.3411

\begin{abstract}
The tourism sector is one of the most powerful generators of economic growth, employment, added value, and services export in the world. In this context, the objective of this article is to discuss tourism and experience tourism possibilities in the region that the Bioceanic Corridor will traverse from the Latin American Integration Route (RILA), involving Brazil, Paraguay, Argentine, and reaching Northern Chile in Antofagasta and Iquique. Regarding methodology, it uses the deductive method and is based on bibliographic and documentary research with access to the articles, indicators, and documents needed. In this regard, regional development issues are presented, followed by experience tourism as a possibility for development, and finally, some indicators and data about tourism are analyzed, seeking an interface with the Bioceanic Corridor. After analyses, it is pointed out that tourism has become one of the fundamental factors for territorial development, presenting new and other values and meanings to the territory, as well as a production resource, discovering another perspective when interpreting rural and natural spaces. Thus, it arises as a new alternative to globalization and, in this context, experience tourism gains prominence considering the significant increase of tourism in the world in 2010, and perspectives until 2030. It is inferred, therefore, that RILA is a great window of opportunity for socioeconomic development through tourism and more specifically experience tourism.
\end{abstract}

Keywords: experience tourism; Bioceanic Corridor; Latin America Integration Route; development.

Resumo: O setor de turismo é um dos mais pujantes geradores de crescimento econômico, emprego, valor agregado e exportações de serviços no mundo. Neste contexto, o objetivo deste artigo é discutir possibilidades de Turismo e de turismo de Experiência na região em que o Corredor Bioceânico perpassará a partir da Rota de Integração Latino Americana (RILA), envolvendo Brasil, Paraguai, Argentina chegando ao Norte do Chile em Antofagasta e Iquique. Com relação à metodologia, utiliza o método dedutivo e se embasa em pesquisa bibliográfica e documental com acesso aos artigos, índicadores e documentos necessários. Para tal, são apresentadas as questões de desenvolvimento regional, em seguida sobre turismo de experiência como possibilidade de desenvolvimento, por fim, analisam-se alguns indicadores e dados sobre o turismo, buscando uma interface com o Corredor bioceânico. Após as análises desenvolvidas aponta-se que o turismo se tornou um dos fatores fundamentais para o desenvolvimento territorial, apresentando novos e outros valores e significados ao território, assim como um recurso de produção, descobrindo um outro olhar ao interpretar os espaços rurais e naturais. Insere-se assim, como uma nova alternativa para a globalização e nesse contexto, o turismo de experiência ganha destaque ao se verificar o expressivo aumento do turismo no mundo de 2010 com perspectivas até 2030. Infere-se, portanto, que a RILA é uma grande janela de oportunidade para o desenvolvimento socioeconômico por meio do turismo e mais especificamente do turismo de experiência.

Resumen: El sector turístico es uno de los generadores de crecimiento económico, empleo, valor agregado y exportaciones de servicios más poderosos del mundo. En este contexto, el objetivo de este artículo es discutir las posibilidades del Turismo y el turismo de Experiencias en la región donde discurrirá el Corredor Bioceánico por la Ruta de Integración Latinoamericana (RILA), involucrando a Brasil, Paraguay, Argentina llegando al Norte de Chile en Antofagasta e Iquique. En relación a la metodología, utiliza el método deductivo y se basa en la investigación bibliográfica y documental con acceso a los artículos, indicadores y documentos necesarios. De ese modo, se presentan temas de desarrollo regional, seguido del turismo de experiencias como posibilidad de desarrollo, y finalmente, se analizan algunos indicadores y datos sobre turismo, buscando una interfaz con

\footnotetext{
${ }^{1}$ Universidade Estadual de Mato Grosso do Sul, Campo Grande, Mato Grosso do Sul, Brasil.

${ }^{2}$ Universidade Católica Dom Bosco, Campo Grande, Mato Grosso do Sul, Brasil.
} 
el Corredor Bioceánico. Tras los análisis desarrollados, se apunta que el turismo se ha convertido en uno de los factores fundamentales para el desarrollo territorial, presentando nuevos y otros valores y significados al territorio, así como un recurso productivo, descubriendo otra mirada a la hora de interpretar lo rural y lo natural. espacios. Así, se inserta como una nueva alternativa a la globalización y en este contexto, el turismo de experiencias cobra protagonismo al constatar el expresivo incremento del turismo en el mundo en 2010 con perspectivas hasta 2030. Se infiere, por consiguiente, que RILA es una gran ventana de oportunidad para el desarrollo socioeconómico a través del turismo y más específicamente el turismo de experiencias.

Palabras-clave: experiencia turística; Corredor Bioceánico; Ruta de integración latinoamericana; desarrollo.

\section{INTRODUCTION}

The Bioceanic Route 3 arose from an idea of the past century, however, had its more concrete beginning in the year 2000, from the summit of presidents of South America, aiming to build state cooperation and the South American continent integration. Its initial name was Integration of Regional Infrastructure (IIRSA) and should form a corridor or integration route with the distribution of these countries' production through the Pacific Ocean. This route would bring the possibility of minimizing operational and financial costs, integration of the continent, would decrease the distance to Asia, and consequently, the product's arrival time.

The first composition of countries in the IIRSA project was proposed by Brazil, Bolivia, Peru, and Chile, forming the interoceanic Corridor, which affected border zones between Brazil and Bolivia. This promoted a bilateral cooperation agreement between the countries, where those zones were the strip of territory making up the borders.

Subsequently, this integration route went through significant changes. One of the main reasons, related to operational aspects in the border zone between Brazil and Bolivia, was the logistic issue, which was seen as a "strangulation" in the relationship between the neighboring countries, raising some questions about the local-global in the issues between the countries.

According to Antônio Simões, Under-Secretary-General at the Ministry of Foreign Affairs, "The IIRSA had the classic view of a corridor of commodities export to outside the continent, which changes to favor projects to increase the integration of internal markets" (LEO, 2011). Thus, the IIRSA original form was altered. By assuming the name "Latin American Integration Route" (RILA), the new route was composed of the following countries: Brazil, Paraguay, Argentine, and Chile, with the initial proposal of a road integration route.

Another very important element in this context, according to UEMS (2019) was the formation of Rila's University Network (UniRILA), created in the second semester of 2016 but constituted, officially, in October 2017, and composed of the universities part of CRIE-MS (Deans Council of the Higher Education Institutions of Mato Grosso do Sul). They are: State University of Mato Grosso do Sul (UEMS), Dom Bosco Catholic University (UCDB), Federal University of Mato Grosso do Sul (UFMS), Federal University of Great Dourados (UFGD), Anhanguera/Uniderp University, and Federal Institute of Mato Grosso do Sul (IFMS). In addition to the CRIE-MS, the National University of Jujuy (UNJu) and National University of Salta (UNSA), in Argentine, University of Antofagasta (UA) and Catholic University of Northern Chile (UC), in Chile, and National University of Asunción (UNA), in Paraguay, are part of the network. This integration allowed the creation of a network

\footnotetext{
${ }^{3}$ In this article, the terms Latin American Integration Route (RILA), Bioceanic Corridor, and Bioceanic Route will be treated as synonyms. The three terms concern the transport road corridor that links Campo Grande, MS, to the ports of Chile in Antofagasta and Iquiqui, passing through Loma Plata in Paraguay, Salta in Argentine, and San Pedro de Atacama in Chile.
} 
between universities, research institutes, government bodies, development institutions, and businesses, to generate, absorb, and disseminate technological innovations and knowledge via cooperation, learning, information exchange, and experiences.

In this sense, by taking this corridor's issues as a whole, we can address in this article experience tourism, as well as regional development and its connections. By analyzing Experience Tourism, we can identify different readings, approaches, and/or movements, which take it whether as a market segment, and the market and marketing view present in neoliberal society, as a rupture movement, the so-called slow movement, of Italian origin, or a way of living and experiencing events and situations.

In this sense, experience tourism requires planning and qualitative and differentiated organization of activities that may welcome groups visiting the territories, interact, factually, with subjects, stories, and local cultures - exclusive, memorable experiences, from local references and knowledge, such as culture, legends, myths, crafts, where material and immaterial manifestations of the location are present and are peculiar to the location, shared the most genuine and authentic way possible (BRASIL, 2010).

Its connection with regional development is that, when faced with urban spaces, with the spontaneity and historical knowledge of the localities involved, often, experience tourism is lost or blends in with the multiple technologies and pieces of information of the contemporary world. According to Costa (2004, p. 32), we might say that what occurs is "[...] a concomitant process of destruction and construction of territories merging different territorial modalities [...] in multiple scales and new ways of territorial articulation".

Nowadays, the perception of cultures as a product has assumed, increasingly, a bias with social implications and presents itself as one of the strengths for tourism in today's Brazil, focusing the emotional perception to the detriment of the historical and consumption view, that is, a change of view happens relative to the tourism product. The experience to be lived is impregnated with symbolisms, stories, customs, cultures, and practices typical of the locations to be visited. "The tourist becomes character [...], acquires the cultural knowledge of the place visited and develops an emotional link, which is a differential factor" (BRASIL, 2010, p. 16).

From these brief conceptualizations, this article proposes to discuss tourism and experience tourism possibilities in the region traversed by the Bioceanic Corridor. The study in its methodological structure uses the deductive method based on bibliographic and exploratory research, in the face of a description and theoretical characterization and the documentary research, by the access to existing documents and indicators about the theme approached. The article is divided into three parts in addition to this introduction and the final considerations. Initially, the regional development issues are discussed, followed by the theoretical and analytical conceptualizations about experience tourism, and finally, indicators and data about tourism are presented and analyzed, with a view to an interface with the Bioceanic Corridor implementation.

\section{REGIONAL DEVELOPMENT: SOME PERCEPTIONS}

Tourism and culture when integrated might strengthen local culture and provide the knowledge and valuation of the community. To understand the relationship between the binomial tourism and culture it is necessary to understand also the interrelation between tourism, culture, and development since

INTERAÇÕES, Campo Grande, MS, v. 22, n. 4, p. 1303-1315, out./dez. 2021. 
[...] local development is indispensable, for the actions established in the cultural and tourist context should have a direct impact on the inhabitants' life, their economic and social conditions, on the future of territories, and this respecting natural and human components. (MAZUEL, 2000, p. 99-100).

Complementing this concept, Catherine Walsh adds that development is a global and dynamic process "[...] between persons, knowledge, learning, and culturally different practices seeking to develop a new meaning between them in their difference" (WALSH, 2001, p. 10-11). This way of thinking development breaks with a Cartesian view logic and perceives a systemic thinking, in a context of complexity and totality. Diverse dimensions make this understanding of development effective, which over the years suffered changes according to Sachs (1997), and are as follows: ethical, social, cultural, ecological, and territorial, which form a global process.

These changes related to the dimensions can be observed from the actors that are present in the territories because:

All territory inhabited by humans is constructed by stories (individual and collective), everyday practices, ways of subsistence, landscapes, objects, favorite places, and marks that define it. All territory can be experienced and invested with meaning by the inhabitants, shapes their culture and the ways of feeling and acting. [...] Territoriality is a universal and legitimate feeling. (FRANCO et al, 2013, p. 150).

For Sachs $(1997,2009$, s.p.), understanding development is understanding its multidimensionality in the following great areas:

i) Social - For the author, there is a need for overcoming bottlenecks related to social inequality, scarcity of labor, unequal income distribution, and lack of access to resources and public services.

ii) Cultural - According to the author, culture can be a strong social link in the promotion of a new development paradigm, by seeking the reconciliation between innovation and tradition, as well as in its capacity to unite people in a global interaction.

iii) Economic - The author emphasizes the need for a balanced economic development to promote food security, continuous modernization of instruments of production, autonomy in scientific and technological research, along with inclusion in the international economy.

iv) Environmental, ecological - Awareness, according to the author, that any economic activity is consolidated in the environment, without prejudice to its diversity.

v) Political - This dimension, according to Sachs, involves governmental strategies aimed at promoting democracy, social cohesion, and the state's organization capacity in implementing a national project.

It is relevant to emphasize that while the dimensions are presented individually, they cannot be seen in isolation but interrelated so development may span equality, equity, and solidarity, propositions which, in Sachs' (2008) view, distinguish the positivity of economic aspects in the face of economy's reductionism.

Observing that development does not concern only economic growth and unlimited material progress, but a concept linked to assuring quality of life and material progress within the natural limits is needed.

Thinking, therefore, of diverse development perspectives, by a simplified look through its efficiency, is to establish processes of production until the consumption of a product, comprising the social system's levels, and seeking to be in harmony with nature (ANTUNES, 2004).

Regional development, then, can be seen and analyzed as a human grouping that encompasses diverse factors, such as religion, culture, and gastronomy, becoming a cultural 
representation, and this construction is symbolic, immaterial, and material and becomes a collective construction involving the values prevailing in the region. In this context, to understand which relations emerge between development and region, we should consider the tone and perspective given to the development issues (MATTEDI, 2015).

In this sense, in the regional or local development bias, the analysis should "[...] start from the recognition of the plurality of differences of the contexts in which these movements operate, along with the diversity in their stories, aims, and conceptions about why one fights and ways of fighting" (LANDER, 2014, p. 53).

Each locality and region must articulate and dialogue on their universal values and local concerns, seeking to reflect upon and analyze their realities, for significations of territory and territorialities, hence, by territory we understand a collective way of defining means and ways of seeking development, despite this being a complex task. Regional development has the following three main characteristics: multidimensionality, multidirectionality, and multisignification (MATTEDI, 2015). It takes place in

[...] a physical space, geographically defined, generally continuous, comprehending city and fields, which is characterized by multidimensional criteria, such as economy, society, culture, politics, and institutions, and a population with relatively distinct social groups interrelating, internally and externally, by means of specific processes, where one can distinguish one or more elements that indicate identity and social, cultural, and territorial cohesion. (BRASIL, 2004, p. 12).

The territories start to have some functions as agents of social change, and importance, recognition, and value (VARGAS, 2009), therefore, in this relationship between development and region, the territories add to tourism activities.

Another significant aspect for regional or local development comprises diverse values and principles, articulated when the region or locality proposes to fulfill them, and these values are universal, not being described in any place (PIKE; RODRÍGUES-POSE; TOMANEY, 2006). Thus, [...] "it is necessary to start from the recognition of the plurality of differences of the contexts in which these movements operate, along with the diversity in their stories, aims, and conceptions about why one fights and ways of fighting" (LANDER, 2014, p. 53).

For Mattedi (2015, p. 63), "[...] to think regional development is to associate relational attributes whose association allows detecting dimensions of reality by way of the contrast of heterogeneous factors".

In what regards local development, the environment does not mean an object to be modified but a means by which development can be carried out. The environment is everything that the culture and imagery have to construct the subjects and their surround, qualitatively (SARTRE; BERDOULAY, 2005). In this perspective, the basis of development are aims such as preservation, environmental conservation, cultural identity, quality of life, participatory development, and productive income generation. To think and analyze local development, it is necessary that the local community feels part of the process where the decision-making, responsibilities, improvements, or the possible transformation into improvements will happen amid the local population and its surround.

In this sense, the tourism sector activities will promote changes in territories of the Bioceanic Route, aiming at a local and regional development that results from the interaction and synergy between the quality of life of the local population (reduction of poverty, 
generation of wealth, and distribution of assets), along with economic efficiency and good public management.

\section{EXPERIENCE TOURISM AS A POSSIBILITY OF DEVELOPMENT}

Tourism, in its dynamics of life, is permeated by contexts that emerge and guide human beings into new healthy experiences of life renewal and awareness of themselves and of the world, drawing the human being's desire to travel and seek happenings - individual experiences catered to through stimuli that we call sensations. The innovative, differential, is a multifunctional activity that allows learning (about geography, cultures, languages, among others) and leisure (rest) and that provides new perspectives on the surround, enabling a global view of the world. These experiences aid people in their development and individual growth (LI, 2000).

The human being is always under construction and in multiple directions or dimensions, thus, the sensorial experience is interlinked with the empirical knowledge and directly with sensations and both merge in the human being. This is a rational being thirsty for living always new experiences that transform him and are perceived by him. By way of experiences we have our sensorial perceptions, that is to say, the ideas of something and it is by way of them and the perceptions felt, that we can elaborate the ideas and describe them.

Although the experiences are individual, they allow the division and stimulation with others, they are the observation of external objects but in the mind, are unique, in that each being has its way of experiencing. They are divided into the following two types: (a) external- properties of objects themselves from where simple ideas of sensation originate, which may be given by a single or several senses. Therefore, they are aimed at what really exists in the known things, color, extension, movement, that is, at the way we observe the objects; (b) internal- those that hold the subjective characteristics of the object, as odor, flavor, varying from subject to subject (ARANHA; MARTINS, 1993; REALE; ANTISERI, 1990).

The relationship between travels and experiences lies in living the novelty, where subjectivity singularly presents itself. One expects diverse sensations, which accompany the moment of experience, when the tourist gets involved; something is made memorable, increasing his learning and knowledge about other cultures.

While the systems are increasingly globalized, the experience in traveling and practicing tourism has specific meanings for the tourist, expressed in subjective contents, that is, desire, widened prospect, personal experience, and issues related to dreams at a given time (LI, 2000; BENI, 2004).

When the human being seeks travels, he looks for something differentiated, unexpected, hopes that they aggregate values, sensations, something different, out of the ordinary, of the sameness, of the routine, and wishes that this is not only a trip to a given place, a new culture, but a fundamental experience in his life, which brings depth.

In this sense, the tourist activity, ergo, seeks the knowledge of cultures, traditions, customs, of the access to new places, of something lived since the beginning of the human being's travels throughout history. Tourism has become one of the fundamental factors for territorial development, presents new and other values and meanings to the territory, enables production resources, finds a new perspective when interpreting rural and natural spaces and, in this way, a new alternative to globalization; it demonstrates other ways of life with differentiated local 
products, concerned with protecting, caring for, and valuing territories and cultures (LEDO; BONÍN; IGLESIAS, 2007).

Still in this perspective of understanding and analysis of the tourism activity, we turn to Andrade (1992, p. 11), who states that "tourism arises from a set of a heterogeneous nature that impedes the constitution of autonomous science and specific independent techniques. It does not have a disciplined and rigid order, nor a methodology of its own". The tourist activity aims at knowing cultures, traditions, customs, new places, something experienced since the beginning of the human being's travels throughout history.

In this sense, we now look at and analyze the tourist system. Basically, two factors make it up: offer and demand. The tourist offer corresponds to the sphere of tourist, natural, and artificial attractions, in their power of attraction. This requires a whole infrastructure to give support, such as lodging, food service, safety, transport, health, information services, among others. The tourist demand, in turn, is formed by consumers, from other locations or not, who make use of the tourist products (RIOS MILAGRES; SOUZA, 2012).

In opening possibilities for other world, life and human being views, experience tourism must be founded on equity, which generates the dignity of human beings and all the other living beings. An experience tourism attentive and connected to the territorialities of bodies through experience, integrated to the challenging cultural demands of Latin America and of the planet, has in the preservation and care of the world one of its aims.

The experience tourist seeks something personal to answer to an inner need, and this type of tourism creates spaces for this person to change. The person deals with feelings and now has new knowledge, which is an opportunity to create spaces and a connection with possibilities of change. The tourist experience, when already consolidated, makes the tourist interact with the location, spaces, he is now a visitor, which then confuses himself with a dweller of the locality, and which can reassess his role in the personal, cultural relations, customs, and judgments, among others.

He can also be seen as a category inside the market segments, where one utilizes a marketing proposal so to add value to the tourism product and so that there is guidance to reach the desired target public. Thus, the tourist experience has, too, a consumer view.

Tourism, as based on the relation of motivation of the human being, in which financial conditions affect its practice, establishes a way of breaking with the routine, distances itself from everyday and routine practices, and establishes a contact zone with cultures, symbologies, and territories, promoting other and new experiences. The tourist sector currently is concerned with providing tourists with knowledge, experiences, and learning, where these may generate emotions, sensations, explicitly or not, innovations, and differences.

\section{BIOCEANIC CORRIDOR AND TOURIST PERSPECTIVES}

According to the Organisation for Economic Cooperation and Developmen (OECD, 2018, s.p.) analyses, several factors will impact tourism in the world, for example, socioeconomic, political and technological, and environmental issues. In this sense, they indicate the following four great general trends:

i. Growth in the demand of tourist visitors;

ii. Appearance and improvement of tourism-related facilitating technology; 
iii. Great relevance on the part of sustainable tourism;

iv. Mobility of the travels.

For OECD (2018), the tourism industry is one of the most powerful generators of economic growth, employment, added value, and services export in the world. Regarding the countries of the Organization for the Cooperation and Economic Development (OECD), the industry is responsible for $4.2 \%$ of the GDP, $6.9 \%$ of the employment, and $21.7 \%$ of services exports, on average. From Figure 1, we can observe the growth in arrival and departure flows of tourists across the world.

Figure 1 - Arrivals and departures of tourists from 1950 until 2050 in million by regions of the world

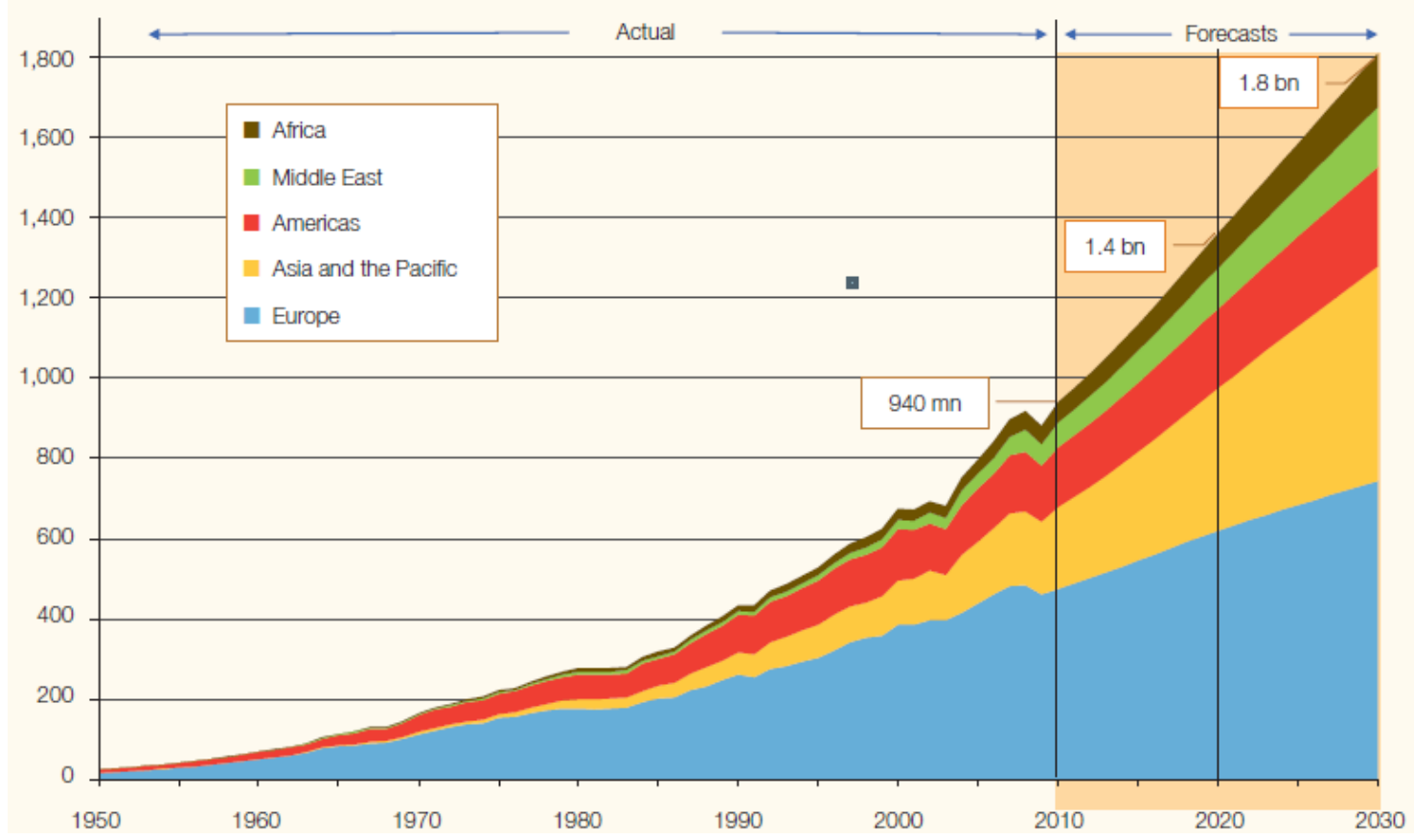

Source: World Tourism Organization (UNWTO, 2016, p. 14).

In Figure 1, we can observe the significant increase of tourism in the world, by regions. It is important to highlight that for 2010 to 2030, these growth forecasts indicate a substantial increase in the industry. The numbers in 1950 were almost derisory and what one observes after 1970 is a great boom, which, according to the estimates, should extend until 2030, or more.

In Brazil, tourism represents 3.7\% of the GDP, if analyzed directly, and $9.6 \%$ of the GDP, considering indirect impacts. As to employment, it generated two million new jobs in 2016 and represented $2.4 \%$ of the total in the country.

The tourism-related numbers and indicators for Brazil are extremely relevant, according to Ministério do Turismo (2019). The most common way of access of international tourists is by air with $65.4 \%$, and then by land, with $31.5 \%$. A relevant datum is the entry of nearly 6.6 million nonresident tourists, most from South America, representing 61.2\%, followed by Europe with 22.1\%, and finally, North America with $10.4 \%$. Specifically, when one analyzes the entry of Argentinian tourists, the numbers are even more important. According to Ministério do Turismo (2019), our neighbors represented around $20 \%$ of the total flow of tourists to Brazil in the decade 2000-10 and this value jumped to $39.8 \%$ in 2017. After the Argentinians, other nationalities important for tourism in Brazil are United States (8.7\%), Paraguay (4.8\%), Chile (4.7), and Uruguay (4.3). 
It is important to highlight that the countries part of the bioceanic route represent, together, about $50 \%$ of the entry of tourists. Thus, this corridor might represent a great advance in facilitating tourism.

This strongly indicates the tourism potential related to the bioceanic route. Most tourists are from South America and enter the country through airports; however, with the possibility of a road corridor, it is very likely that these numbers are even more significant.

The route, in its association with tourist activity, is an initiative that encompasses economic, social, environmental activity, among other areas of development. The development of tourism practices in this region might signify the great risk of the loss of much cultural knowledge, transformations in the landscape, and bring about environmental degradation (NOGUEIRA, 1990; 2002; LEITE, 2003; FERNANDES, 2002; BARROS, 1998).

The coming of tourists to the RILA and the consequent abrupt access into this habitat end up changing the life and way of being of the men entering its territories and territorialities. Tourism and culture, when integrated, can strengthen local culture, providing knowledge and the valuation of the community. To understand the relation between the binomial tourism and culture it is necessary to understand also the interrelation between tourism, culture, and development since

[...] local development is indispensable, for the actions established in the cultural and tourist context should have a direct impact on the inhabitants' life, their economic and social conditions, on the future of territories, and this respecting natural and human components. (MAZUEL, 2000, p. 99-100).

Catherine Walsh adds: development is a global and dynamic process "[...] between persons, knowledge, learning, and culturally different practices seeking to develop a new meaning between them in their difference" (WALSH, 2001, p. 10-11). This way of thinking development breaks with a Cartesian view logic and perceives a systemic thinking, in a context of complexity and totality.

The justification for the pursuit of possible answers or perspectives for the above issues was based on different aspects, instances, and arguments. Among the aspects that guide our hypotheses, we identify the culture(s) stemming from the confluence of peoples settled historically in the Pantanal region in different countries. We highlight that culture is not static and that it undergoes change over time, as a field instituted by the action of men, who act by choosing freely their acts, giving them meaning, purpose, and value (CHAUÍ, 2003).

It is important to stress that the idea of culture acknowledges diversity, therefore one understands culture as something from the social and non-material reality, in that it spans various real aspects (CUCHE, 2002).

Thus, it is not possible to think, analyze, and discuss aspects or elements of RILA's tourism proposal in the pursuit of possible implementation relationships in tourism activity, in the perspectives of the interculturality and multidimensionality of development as something isolated; one should understand the historical context of which it is a part.

\section{FINAL CONSIDERATIONS}

This article aimed at discussing tourism and experience tourism possibilities in the region traversed by the Bioceanic Corridor. For this purpose, we discussed matters such as regional development, experience tourism as a possibility of development, indicators and data about 
tourism seeking an interface with the bioceanic corridor. Subsequently, it was possible to raise the following considerations:

- The Latin American Integration Route (RILA) and consequently the Bioceanic Corridor, is a great window of opportunity-for socioeconomic development through tourism and more specifically experience tourism.

- Regional development can be seen and analyzed as a human grouping that encompasses several other factors, such as religion, culture, gastronomy, becoming a cultural representation, and this construction is symbolic, immaterial, and material and becomes a collective construction involving the values prevailing in the region.

- The tourism sector activities can promote changes in territories of the route, aiming at a local and regional development.

- Local development results from the interaction and synergy between the quality of life of the local population (reduction of poverty, generation of wealth, and distribution of assets), along with economic efficiency and good public management.

- Tourism has become one of the fundamental factors for territorial development, presents new and other values and meanings to the territory, has become a production resource, finds a new perspective when interpreting rural and natural spaces, and in this way, a new alternative to globalization. In this context, experience tourism gains prominence.

- The tourism industry is one of the most powerful generators of economic growth, employment, added value, and services export in the world.

- Countries part of the route, Argentine, Paraguay and Chile, are very relevant in the Brazilian tourism.

A significant increase of tourism in the world can be observed for 2010 until 2030.

In this sense, society, state, organizations, and businesses must be prepared and improving themselves constantly to seize the window of opportunity for experience tourism that will result from RILA's bioceanic road corridor, which offers a possibility of socioeconomic development in the region.

\section{REFERENCES}

ARANHA, Maria Lucia de Arruda; MARTINS, Maria Helena Pires. Filosofando: introdução à filosofia. 2. ed. São Paulo: Moderna, 1993.

ANTUNES, Manuel de Azevedo. Do crescimento econômico ao desenvolvimento humano em tempos de globalização. Revista Lusófona de Ciências Sociais, Lisboa, n. 1, p. 73-83, 2004.

ANDRADE. José Vicente de. Fundamentos do Turismo. 3. ed. Ática. São Paulo.1992

BARROS, Abílio. Gente pantaneira: (crônicas de sua história). Rio de Janeiro: Lacerda Editores, 1998.

BRASIL. Ministério do Turismo. Secretaria de Políticas de Turismo. Diretrizes para o Desenvolvimento do Turismo Rural. Brasília, DF: Ministério do Turismo, 2004. Available at: http://www.turismo.gov.br/ sites/default/turismo/o_ministerio/publicac oes/downloads_publicacoes/Diretrizes_Desenvolvimento_ Turismo_Rural.pdf. Access on: 7 May 2007.

BRASIL. Ministério do Turismo. Manual tour da experiência 2010: conceituação. Brasília, DF: Ministério do Turismo, 2010. Available at: http://www.tourdaexperiencia.com.br/arquivos/manual_conceituacao. pdf. Access on: 3 Mar. 2010. 
BRASIL. Ministério do Turismo. Anuário estatístico 2019-ano base 2018. Available at: http://dadosefatos. turismo.gov.br/2016-02-04-11-53-05.html. Access on: 8 Sept. 2019.

BENI, Mario Carlos. Turismo: da economia de serviços à economia da experiência. Revista Turismo - Visão e Ação, Balneário Camboriú, v. 6, n. 3, p. 295-305, Sept./Dic. 2004. Available at: http://www6.univali.br/ seer/index.php/rtva/article/view/1063. Access on: 5 Mar. 2015.

CHAUI, Marilena. Convite à filosofia. São Paulo: Ed. Ática, 2003.

COSTA, Rogério Haesbaert. O mito da desterritorialização: do "fim dos territórios" a multiterritorialidade. 2. ed. Rio de Janeiro: Bertrand Brasil, 2004.

CUCHE, Denys. A noção de cultura nas ciências sociais. 2. ed. Tradução de Viviane Ribeiro. Bauru: Edusc, 2002.

FERNANDES, Frederico Augusto Garcia. Entre histórias e tererés: o ouvir da literatura pantaneira. São Paulo: Ed. UNESP, 2002.

FRANCO, José Luiz de Andrade; DRUMMOND, José Augusto; GENTILE, Chiara; AZEVEDO, Aldemir Inácio. Biodiversidade e ocupação humana do Pantanal Mato-grossense: conflitos e oportunidades. Rio de Janeiro: Garamond, 2013.

LANDER, Edgardo. Crisis civilizatórias, límites del planeta, assaltos a la democracia y pueblos en resistência. In: QUINTERO, Pablo (Ed.). Crisis civilizatória, desarollo y buen vivir. Ciudad Autónoma de Buenos Aires: Del Signo, 2014. p. 27-58.

LEDO, Andrés Precedo; BONÍN, Arturo Revilla; IGLESIAS, Alberto Miguez. El turismo cultural como factor estratégico de desarrollo: el camino de Santiago. Estudios Geográficos, [s.I.], LXVIII, n. 262, p. 205-34, Jan./June 2007. Available at: http://estudiosgeograficos.revistas.csic.es/index.php/estudiosgeograficos/ article/vie w/11/8. Access on: 24 fev. 2015

LEITE, Eudes Fernando. Marchas na história: comitivas e peões-boiadeiros no Pantanal. Brasília, DF: Ministério da Integração Nacional; Campo Grande, MS: Ed. UFMS, 2003.

LEO, S. Integração sul-americana volta à agenda. O Outro lado da notícia, [s.I.], 2011. Available at: http:// www.outroladodanoticia.com.br/inicial/. Access on: 15 July 2021.

LI, Yinping. Geographical consciousness and tourism experience. Annals of Tourism Research, [s.l.], v. 27, n. 4, p. 863-83, Oct. 2000. Available at: http://www.sciencedirect.com/science/article/pii/ S0160738399001127. Access on: 23 Feb. 2015.

MATTEDI, Marcos Antônio. Pensando com o desenvolvimento regional: subsídios para um programa forte em desenvolvimento regional. Revista Brasileira de Desenvolvimento Regional, Blumenau, v. 2, n. 2, p. 59-105, June 2015.

MAZUEL, Luc. Patrimônio cultural e turismo rural: o exemplo francês. In: ALMEIDA, Joaquim Anécio; RIEDL, Mário. Turismo rural: ecologia lazer e desenvolvimento. Bauru, SP: EDUSC, 2000. p. 95-115.

NOGUEIRA, Albana Xavier. O que é Pantanal. São Paulo: Brasiliense, 1990. [Coleção Primeiros Passos]. NOGUEIRA, Albana Xavier. Pantanal: homem e cultura. Campo Grande, MS: Ed. UFMS, 2002.

ORGANISATION FOR ECONOMIC COOPERATION AND DEVELOPMEN [OECD]. Organisation for economic cooperation and developmen OECD tourism trends and policies. Paris: OECD Publishing, 2018. Available 
at: http://dx.doi.org/10.1787/tour-2018-en. Access on: 10 Aug. 2019.

PIKE, Andy; POSE-RODRIGUES, Andrés; TOMANEY, John. Desarrollo local y regional. Valencia: Universitat de Valencia, 2006.

REALE, Giovani; ANTISERI, Dario. História da Filosofia: do Humanismo a Kant. São Paulo: Paulinas, 1990. (Coleção Filosofia, v. 2.).

RIOS MILAGRES, Vanesa; SOUZA, Lucas Barbosa. Observando la comunidad local y su involucramiento con el turismo: un abordaje perceptivo sobre el paisaje del distrito Taquarucu, Palmas-TO, Brasil. Estudios y perspectivas en turismo, [s.l.], v. 21, n. 6, 2012. Available at: https://scholar.google.com.br/scholar. Aceso em 20 abril 2020,

SACHS, Ignacy. Caminhos para o desenvolvimento sustentável. Rio de Janeiro: Garamond, 2009.

SACHS, Ignacy. Desenvolvimento: includente, sustentável, sustentado. Rio de Janeiro: Garamond, 2008. $151 \mathrm{p}$.

SACHS, Ignacy. Desenvolvimento numa economia mundial liberalizada e globalizante: um desafio impossível? Estudos Avançados, São Paulo, v. 11, n. 30, p. 213-42, May/Aug. 1997.

SARTRE, Xavier Arnauld; BERDOULAY, Vicent. Teoria do sujeito, geografia e desenvolvimento local. Novos Cadernos NAEA, Belém do Pará, v. 8, n. 2, p. 109-24, Dic. 2005.

UNIRILA. UniRila: Integrar caminhos, povos e conhecimentos no coração da América Latina. Revista UniRila, [s.I.], 2019. Available at: http://www.uems.br/unirila/. Access on: 3 Sept. 2019.

VARGAS, Icléia Albuquerque de. Porteiras assombradas do paraíso: embates da sustentabilidade socioambiental no Pantanal. Campo Grande, MS: Ed. UFMS, 2009.

WALSH, Catherine. La educación intercultural en la educación. Peru: Ministerio de Educación, 2001. [Mimeografado].

World Tourism Organization [UNWTO]. Tourism Highlights 2016 Edition. UNWTO, 2016. Available at: http://www.dadosefatos.turismo.gov.br/images/pdf/estatisticas_indicadores/UNTWO_Tourism_ Highlights_2016_Edition.pdf. Access on: 3 Sept. 2019.

\section{About the authors:}

Débora Fittipaldi Gonçalves: PhD Student of the Post-Graduation Strictu Sensu Program in Local Development at the Dom Bosco Catholic University (UCDB). Doctorate with partial completion at the University of Barcelona (UB) through the Program of Management of Culture and Heritage, with a CAPES' scholarship. Doctorate and Masters in Regional Development at the Regional University of Blumenau (FURB-SC). Specialist in Methodology of Higher Education at the University Centre of the Grande Dourados Region (UNIGRAN). Graduated in Tourism at UCDB and Pedagogy at UNIGRAN. Currently, is the coordinator and a professor of the Tourism Major department at the State University of Mato Grosso do Sul (UEMS), in Campo Grande. E-mail: defittipaldi@uems.br, Orcid: https://orcid.org/0000-0002-4664-8174

Mateus Boldrine Abrita: Doctorate in Economics at the Federal University of Rio Grande do Sul (UFRGS). Master's Degree in Economic Sciences at the State University of Maringá (UEM). 
Graduated in Economic Sciences at the Federal University of Mato Grosso do Sul (UFMS). Currently full Professor of the State University of Mato Grosso do Sul (UEMS), teaching in the Geography Major, both Licentiate and Bachelor's degree. Advisor of interinstitutional relations and strategic projects at UEMS. Coordinator of the General Padilha Border Studies Center, and of the laboratory of efficiency and innovation in Mato Grosso do Sul's management (LAB-GEIMS). Vice-leader of the Group of Studies in Boards, Tourism and Territory (GEFRONTTER). Researcher of the Development's Structuralist Macroeconomics Group.E-mail: mateusabrita@hotmail.com, Orcid: https://orcid.org/0000-0002-3327-4556

Arlinda Cantero Dorsa: Currently attending the postdoctoral internship at the Augusto Motta University Center (UNISUAM), in the Master's Degree and Doctorate Program in Local Development. Doctorate in Portuguese Language at the Pontifical Catholic University of São Paulo (PUC-SP). Master's Degree in Communication and Languages at the Mackenzie Presbyterian University. Graduated in Languages in French at the Dom Aquino Philosophy, Science and Languages College. Graduated in Pedagogy at the Urubupungá Education, Science and Languages College. Full Professor of the Dom Bosco Catholic University (UCDB), in the Law Course. Professor and vice-coordinator of the Post-Graduate Program in Local Development Master's Degree and Doctorate of UCDB. Member of the Historic and Geographic Institute of Mato Grosso do Sul. Leader of the Group of Research in Cultural Heritage, Rights and Diversities, and vice-leader of the Group of Research and Studies in Educational Technology and Distance Learning (GEDEC) of UCDB. Coordinates the project "Bioceanic Route and UNIRILA (Universities of the Route of Latin American Integration): Learning the existing potentialities as new spaces of development and innovative practices - Continuity", and the project "Migratory governances in Brazil: Contemporary challenges in the 2030 ONU agenda". E-mail: acdorsa@ucdb.br, Orcid: http://orcid.org/0000-0002-1120-0273 
